\title{
Suppression of the MEK/ERK Signaling Pathway Reverses Depression-like Behaviors of $\mathrm{CRF}_{2}$-Deficient Mice
}

\author{
Cedomir Todorovic*,1,2,3, Tessi Sherrin ${ }^{1,3}$, Matthew Pitts ${ }^{3}$, Cathrin Hippel ${ }^{2}$, Martin Rayner ${ }^{1,3}$ and \\ Joachim Spiess ${ }^{1,2}$ \\ 'Specialized Neuroscience Research Project 2, John A Burns School of Medicine, University of Hawaii, Honolulu, HI, USA; ${ }^{2}$ Molecular \\ Neuroendocrinology Laboratory, Max Planck Institute of Experimental Medicine, John A Burns School of Medicine, University of Hawaii, Honolulu, \\ HI, USA; ${ }^{3}$ Department of Cell and Molecular Biology, John A Burns School of Medicine, University of Hawaii, Honolulu, HI, USA
}

\begin{abstract}
The neuropeptide corticotropin-releasing factor (CRF) plays a critical role in the proper functioning of the stress response system through its actions on its receptors, $C R F$ receptor I $\left(C R F_{1}\right)$ and $C R F$ receptor $2\left(C_{2} F_{2}\right)$, located at multiple anatomical sites. Clinical data indicate that stress response dysfunctions, such as excessive CRF activity and hyperstimulation of CRF 1 , are present in a range of stressrelated disorders, including depression and anxiety disorders. Our previous work along with that of other laboratories has demonstrated that mice deficient in $\mathrm{CRF}_{2}\left(\mathrm{CRF}_{2}-/-\right)$ display increased anxiety and depression-like behaviors. In this study, we found $\mathrm{CRF}_{2}-/-$ mice display increased hippocampal levels of activated (phosphorylated) mitogen-activated protein kinase (MAP kinase)/ERK kinase (MEK), extracellular signal-regulated kinases I and 2 (ERKI/2), and ribosomal protein S6 kinases I (RSKI). These changes can be explained by overactive hippocampal $C R F_{1}$, in view of the finding that the application of the nonselective CRF receptor antagonist [Glu ${ }^{11,16}$ ] astressin ([Glu $\left.{ }^{1,16}\right]$ Ast) into the dorsal hippocampus of mutant mice returned the levels of the phosphorylated proteins to baseline. Moreover, inhibition of the hippocampal MEK/ERK pathway with the specific MEK inhibitor U0I26, decreased depression-like behaviors in the forced swim test and tail suspension test of $\mathrm{CRF}_{2}-/-$ mice. Similarly, treatment with [Glu ${ }^{11,16}$ ]Ast reversed depression phenotype of $\mathrm{CRF}_{2}-$ I- mice without affecting the phenotype of wild-type littermates. Our results support an involvement of CRF receptors in the development of depression, such that elevated hippocampal CRF , activity, in the absence of $\mathrm{CRF}_{2}$, produces a depression-dominated phenotype through the activation of the MEK/ERK pathway.

Neuropsychopharmacology (2009) 34, I4I6-|426; doi:I0.1038/npp.2008. I78; published online 8 October 2008
\end{abstract}

Keywords: CRF; $C R F_{1}$; hippocampus; MEKJERK; knockout mouse; depression

\section{INTRODUCTION}

Depression is a devastating illness that affects approximately $17 \%$ of the population at some point in life, resulting in major social and economic consequences (Kessler, 1997). Evidence links stress, and the sensitivity of the individual to stressful stimuli, to the development of depression. The stress response is essential for adaptation and homeostatic balance. However, chronic stress can speedup disease, cause neural degeneration, and lead to depression or other affective disorders (Hammen, 2005).

Corticotropin-releasing factor (CRF) is a 41-residue polypeptide that plays a key role in integrating the endocrine, autonomic, and behavioral responses to stress (Vale et al, 1981). CRF exerts its action through G-protein-

\footnotetext{
*Correspondence: Dr C Todorovic, Specialized Neuroscience Research Project 2, John A Burns School of Medicine, University of Hawaii, 65I Ilalo St Honolulu, HI, 968I3, USA, Tel: + I 808692 I574, Fax: + I 808692 197, E-mail: cedomir@hawaii.edu Received 10 May 2008; revised 5 September 2008; accepted 8 September 2008
}

coupled receptors $\left(\mathrm{CRF}_{1}\right.$ and $\left.\mathrm{CRF}_{2}\right) . \mathrm{CRF}_{1}$ is expressed in high levels in neocortical areas, specifically, the basolateral and medial nucleus of the amygdala, anterior pituitary, hypothalamic nuclei, and cerebellar Purkinje cells among others. $\mathrm{CRF}_{2}$ has been detected in more discrete brain regions, including the dorsal raphe nucleus (DRN), lateral septum, ventromedial hypothalamus, and cortical nucleus of the amygdala (Chalmers et al, 1995; Van Pett et al, 2000).

Compelling evidence indicates that central CRF circuits are hyperactive in major depression. The most prominent evidence comes from clinical studies showing that a subset of severely depressed patients exhibit increased CRF concentrations in the cerebrospinal fluid, elevated expression of CRF in the paraventricular nucleus of the hypothalamus, increased CRF-immunoreactivity in the prefrontal and frontal cortex, locus coeruleus, and median and dorsal raphe nuclei, and decreased CRF-binding sites in the frontal cortex (Arborelius et al, 1999; Hauger et al, 2006; Schüle, 2007). These observations have been reinforced by behavioral studies in which central administration of CRF, preferentially binding to $\mathrm{CRF}_{1}$, resulted in behavioral changes, including anxiety, motoric disturbances, and sleep, 
anorexia, and vegetative abnormalities (Heinrichs and Koob, 2004), which are cardinal symptoms of depression. Moreover, behavioral studies of transgenic mice with modified expression of CRF or CRF receptors support the notion that CRF overexpression increases anxiety-like behaviors, whereas deficiency of $\mathrm{CRF}_{1}$ (Smith et al, 1998; Timpl et al, 1998) or $\mathrm{CRF}_{2}$ genes (Bale et al, 2000; Kishimoto et al, 2000) reduces or heightens anxiety, respectively.

In addition, $\mathrm{CRF}_{2}-/-$ mice tested in the forced swim test (FST) display increased immobility as an indicator of depression-like behavior (Bale and Vale, 2003; Todorovic et al, 2005). When treated with the $\mathrm{CRF}_{1}$ antagonist, antalarmin, the time spent immobile decreases, whereas swimming and climbing, ie, active stress coping behavior increases (Bale and Vale, 2003). Although there were no controls to indicate whether antalarmin reduces depressionlike behavior in wild-type mice, the effectiveness of $\mathrm{CRF}_{1}$ antagonism might be explained by the previous finding that $\mathrm{CRF}_{2}-/-$ mice show increased CRF levels in the central nucleus of the amygdala and increased urocortin 1 (Ucn1) levels in the Edinger Westphal nucleus (Bale et al, 2000). The specific interaction, however, between $\mathrm{CRF}_{2}$ deletion effects and $\mathrm{CRF}_{1}$ on depression-like behavior remains unresolved.

$\mathrm{CRF}_{1}$ signaling through the extracellular signal-regulated kinases 1/2 (ERK1/2)-mitogen-activated protein kinase (MAPK) cascade has been observed in neuronal, cardiac, and myometrial cells, as well as in recombinant expression systems (Hauger et al, 2006). In vivo, intracerebroventricular (i.c.v.) CRF administration increases phosphorylated ERK1/2 (pERK1/2) levels specifically in the CA3 and CA1 hippocampal subfields and basolateral complex of the amygdala, both structures related to external environmental information processing and behavioral aspects of stress (Refojo et al, 2005). Moreover, recent findings suggest that the ERK pathway in the hippocampus is involved in the molecular pathophysiology of depression and affective regulation, so ERK1/2 might be a significant target to examine the neuronal mechanisms of affective disorders induced by stress (Duman et al, 2007; Tronson et al, 2008).

On the basis of these considerations, this study investigated the hypothesis that elevated phosphorylation of hippocampal ERK1/2 through the enhanced activation of $\mathrm{CRF}_{1}$ might be responsible for depression-like behaviors observed in $\mathrm{CRF}_{2}-\mathrm{I}-$ mice, and that the ERK signaling pathway might be a therapeutically relevant target of the antidepressant-like actions of CRF1 antagonists.

\section{MATERIALS AND METHODS}

\section{Animals}

$\mathrm{CRF}_{2}-/-$ mice were generated using standard gene targeting procedures with embryonic stem (ES) cells derived from the $129 / \mathrm{SvJ}$ mouse strain (Kishimoto et al, 2000). Briefly, genomic clones encompassing the $\mathrm{CRF}_{2}$ transcript were obtained from a $129 / \mathrm{SvJ}$ mouse library. A targeting vector was constructed in which the third intracellular loop of $\mathrm{CRF}_{2}$ was replaced by neomycinresistant gene sequences. This knockout, however, does not target the soluble $\mathrm{CRF}_{2}-\alpha$ isoform, which lacks functional exons 8-14 present in the standard form that contains the region coding for the third intracellular loop targeted in the knockout (Chen et al, 2005). ES cells derived from 129/SvJ mice were electroporated with the targeting construct and selected with G418/ganciclovir using southern-blot analysis. Heterozygous ES cell clones were injected into C57BL/6J blastocysts to generate chimeric mice. Chimeric founder males were bred to $\mathrm{C} 57 \mathrm{BL} / 6 \mathrm{~J}$ females to generate $\mathrm{F} 1$ heterozygous offspring. Homozygous $\mathrm{CRF}_{2}$ mice were obtained from F1 intercrosses. Genotyping was performed by PCR-based DNA amplification using primer sets recognizing the third intracellular loop of $\mathrm{CRF}_{2}$ or the neomycin resistance coding sequence as described previously (Kishimoto et al, 2000). Data reported here were obtained using F3-F5 generation hybrids. From the age of 8 weeks, mice were individually housed in standard Macrolon cages with free access to food and water. Mice were 10 weeks of age at the time of testing. They were kept in a $12 \mathrm{~h}$ light-dark cycle with lights switched on at 0700 hours. The experiments were performed during the light phase. All experimental procedures were in compliance with the European Council Directive (86/609/EEC) by the permission of the Animal Section Law enforced by the District Government of Braunschweig, Lower Saxony, Germany. Experiments performed in Honolulu were approved by the University of Hawaii Animal Care Committee in accordance with National Institutes of Health guidelines. All efforts were made to minimize animal suffering. For each behavioral test and molecular study, different mice were used.

\section{Cannulation and Administration of Drugs}

The injection system (C235; Plastics One, Roanoke, VA) consisted of double-guided cannulae, dummy, and a cap. Double-guided cannulae (internal, 28 gauge; guide, 22 gauge) were inserted bilaterally into the dorsal hippocampi (intrahippocampal injection; $2 \mathrm{~mm}$ posterior to the bregma, $2 \mathrm{~mm}$ lateral, and $1.6 \mathrm{~mm}$ below the dural surface for the CA1 region (Franklin and Paxinos, 1997), and affixed to the skull by dental cement. The animals were allowed to recover for 7-10 days before the experiments started. On the day of the experiment, the mice were exposed to a light isoflurane anesthesia, the cap and the dummy were removed, and solutions were delivered through an injector linked to two Hamilton microsyringes with plastic tubing. The drugs were administered bilaterally by a microinjector (CMA/Microdialysis, Sweden) over a 30 -s period, so that $0.25 \mu$ l volume was injected to each side. The cannula placement was verified for each mouse immediately after the behavior experiments by histological examination of the brains following methylene blue injection $(0.25 \mu \mathrm{l}$ per side). Only data obtained from mice with correctly inserted cannulae were included in the statistical analysis. For behavioral studies, 16 of 114 operated animals were excluded because of incorrect cannula placement. The MAPK/ERK kinase (MEK) inhibitor 1,4-diamino-2,3-dicyano-1,4-bis(o-aminophenylmercapto) butadiene (U0126) (Promega, Madison, WI) was dissolved in $100 \%$ DMSO to a final stock concentration of $2 \mathrm{mg}$ per $\mathrm{ml}$. For behavioral testing, the drug was diluted with artificial CSF (aCSF; in mM: $120 \mathrm{NaCl}$, $2.4 \mathrm{KCl}, 1.2 \mathrm{CaCl}, 1.2 \mathrm{MgCl}, 0.9 \mathrm{NaH} 2 \mathrm{PO} 4,1.4 \mathrm{Na} 2 \mathrm{HPO} 4$, and 0.3 ascorbic acid) to yield final concentrations of 
$250 \mu \mathrm{g} 0.25 \mu \mathrm{l}$ per side. We have demonstrated previously that the employed dose of this inhibitor is effective in vivo and significantly impairs the phosphorylation of its downstream targets during fear conditioning (Ahi et al, 2004). U0126 is a specific ERK/MAPK inhibitor and has no effect at a range of concentrations on other kinases, such as PKA, calcium-calmodulin kinase II, or PKC (Roberson et al, 1999). The vehicle was made as above with the omission of U1026. The highly potent nonselective CRF receptor antagonist, $\left[\mathrm{Glu}^{11,16}\right]$ astressin $\left(\left[\mathrm{Glu}^{11,16}\right]\right.$ Ast; $\mathrm{IC}_{50}=3.3 \mathrm{nM}$ for $\mathrm{CRF}_{1}$ and $\mathrm{IC}_{50}=1.1 \mathrm{nM}$ for $\mathrm{CRF}_{2}$; Eckart et al, 2001), was initially dissolved in $10 \mathrm{mM}$ acetic acid before distilled water and two-fold concentrated sterile, aCSF, was added to obtain the final dose of $120 \mathrm{pmol}(215 \mathrm{ng} 0.25 \mu \mathrm{l}$ per side) of ([Glu $\left.{ }^{11,16}\right]$ Ast. Solution was adjusted to $\mathrm{pH}$ 7.4. The dose used was selected on the basis of its ability to prevent behavioral effects of the wide range of doses $(0-35 \mathrm{pmol})$ of oCRF preferentially binding to $\mathrm{CRF}_{1}$ (Eckart et al, 2001). The vehicle was made as above with the omission of ([Glu $\left.{ }^{11,16}\right]$ Ast. The number of mice in behavioral experiments was 6-8 per group. The number of mice in each experiment is specified in the corresponding figure legends.

\section{Tail Suspension Test}

On the day of the tail suspension test (TST), $\mathrm{CRF}_{2}-I-$ mice and their wild-type littermates were transferred to the experiment room and allowed to acclimatize for $1 \mathrm{~h}$. Mice were injected intrahippocampally (i.h.) with vehicle (50\% DMSO), or U0126 (250 $\mu \mathrm{g} 0.25 \mu \mathrm{l}$ per side), $30 \mathrm{~min}$ before the TST trial. An automated tail-suspension apparatus (TSE Systems, Bad Homburg, Germany), with a tail hanger connected to a precision linear load cell, was used. In all, $1 \mathrm{~cm}$ of the mouse's tail was inserted into the tail hanger and secured with nonirritating adhesive tape. Mice remained suspended by the tail, at a height of $35 \mathrm{~cm}$ from the tabletop, for $6 \mathrm{~min}$. During this time the load cell recorded the mouse's movements and transmitted the information to a central computer, which then recorded the rate of immobility within the course of the session, and calculated total duration of immobility. Decreases in basal levels of immobility are highly predictive of antidepressant efficacy (Cryan et al, 2005).

\section{Forced Swim Test}

For the FST, a fresh group of $\mathrm{CRF}_{2}-/-$ mice and their wildtype littermates were subjected to swim sessions in individual glass cylinders (height $39 \mathrm{~cm}$, diameter $21.7 \mathrm{~cm}$ ) containing water, $15 \mathrm{~cm}$ deep, at $23-25^{\circ} \mathrm{C}$. On Day 1 , all animals were placed in the cylinder for a preswim session of $12 \mathrm{~min}$. On the test day $24 \mathrm{~h}$ later (day 2), the mice were subjected to a test swim session for $5 \mathrm{~min}$. Mice were injected on day 1 , i.h., with vehicle (50\% DMSO in aCSF), or U0126 $(250 \mu \mathrm{g} 0.25 \mu \mathrm{l}$ per side) $30 \mathrm{~min}$ before the preswim session of $12 \mathrm{~min}$. As $\mathrm{CRF}_{2}-/-$ mice did not display depression-like phenotype during a test swim on day 2, pharmacological interventions were omitted for that day. The water was changed between subjects. All sessions were recorded by a video camera positioned directly above the cylinder. A competent observer blind to treatment scored the videotapes. The behavioral measure scored was the duration of floating, defined as time spent still or only using righting movements to keep the head above water, and the latency to assume immobile posture. Increase in floating time and decrease in latency time were interpreted as an increase of depression-like behavior (Porsolt et al, 1978).

\section{Locomotor Activity Test}

Locomotor activity was measured in a Plexiglas chamber $(35 \mathrm{~cm} \times 20 \mathrm{~cm} \times 20 \mathrm{~cm})$ located in a box $(58 \mathrm{~cm} \times 30 \mathrm{~cm} \times 27 \mathrm{~cm})$ with a gray interior and a 12 -W light at the ceiling. Activity (total distance traveled in centimeters) was measured during a $30-\mathrm{min}$ period by an infrared beam system (detection rate $10 \mathrm{~Hz}$ ) and analyzed by TSE software (VideoMot 2, Bad Homburg, Germany).

\section{Immunohistochemistry of Phospho-ERK1/2}

$\mathrm{CRF}_{2}-/$ - mice and their wild-type littermates were used to look at levels of ERK1/2 expression in the hippocampus without any prior treatment or behavioral analysis. Mice were deeply anesthetized and transcardially perfused with ice-cold phosphate-buffered saline (PBS; pH 7.4), followed by $0.1 \mathrm{M}$ phosphate buffer, $\mathrm{pH}$ 7.4, containing $4 \%$ paraformaldehyde ( $\mathrm{pH} 7.4,150 \mathrm{ml}$ per mouse). The brains were postfixed for $48 \mathrm{~h}$ in the same fixative (4\% PFA) and then immersed for $24 \mathrm{~h}$ each in 10,20 , and $30 \%$ sucrose in PBS. The brains were cryosectioned (50 $\mu \mathrm{m}$ slices). Immunostaining was performed using the free-floating method with mouse phospho-ERK1/2 (Thr202/Tyr204) monoclonal antibody (1:500; Cell Signaling Technology, Beverly, MA), followed by biotinylated secondary antibody and avidin-biotin complex system (Vector $A B C$ kit, Vector Laboratories, Burlingame, CA). Diaminobenzidine (DAB) (Sigma tablet set) was used as a chromogen. For immunofluorescence analysis of pERK1/2, a similar protocol as the one used for perfusion and postfixation of mice brains was followed. Immunofluorescent labeling was performed as described previously (Sherrin et al, 2008). Briefly, sections $(50 \mu \mathrm{m}$ thick) were washed with TBS before overnight incubation with mouse monoclonal anti-ERK1/2 IgG (Cell Signaling Technology) at 1:200 dilution followed by incubation with biotinylated antimouse secondary antibody (1:400; Vector Labs). The sections were washed, fluorescin avidin DCS (Vector Labs) was applied, rendering green fluorescence. The sections were mounted on Superfrost Plus slides (Menzel Glaser, Braunschweig, Germany) using vectashield mounting medium (Vector Labs) to prevent rapid photobleaching of fluorescein. An Axioimager Zeiss microscope and Zeiss Axio Cam HRM camera were used for the observations and photography of the slides, respectively.

\section{Phospho-ERK1/2 Density Measurements}

The CA1 and CA3 hippocampal subfields, the dentate gyrus, and the corpus callosum of mouse were outlined at the anatomical coordinates -1.4 to $-1.6 \mathrm{~mm}$ posterior to the bregma (Franklin and Paxinos, 1997). All photographs were taken at $\times 20$ magnification using identical light intensity and exposure times. All images were imported into the NIH image analysis program version 1.63 , and the black and 
white images were inverted to simulate dark-field illumination. For densitometric analysis, two separate standard area contours were drawn for each digital image. The selected contour for positive pERK immunoreactivity delineated the CA1 (encompassing dorsal stratum pyramidale, and partially strata radiatum, and oriens), CA3 hippocampal subfields (encompassing dorsal stratum pyramidale, and partially strata radiatum- and lucidum-containing mossy fibers from the granule cells), or dentate gyrus (encompassing dorsal deep hilus and hilar border with granule cell layer). The other contour for nonspecific DAB background lacking pERK immunoreactivity delineated corpus callosum from the same brain section. Because the corpus callosum had less variation and a low optical value reflecting less immunoreactivity, it was chosen as the reference. Mean optical density numbers were derived by subtracting the nonspecific $\mathrm{DAB}$ background from the positive pERK immunoreactive areas.

\section{Protein Extraction and Western Blot Analysis}

Hippocampi were dissected out and immediately homogenized at $4{ }^{\circ} \mathrm{C}$ with a plastic homogenizer in a Cell Lysis buffer (Cell Signaling, Beverly, MA) and a protease and phosphatase inhibitor cocktail (Pierce, Rockford, IL). The insoluble material was removed by centrifugation at $14000 \mathrm{~g}$ for $10 \mathrm{~min}$ at $4{ }^{\circ} \mathrm{C}$. Protein concentrations were determined by the Bradford method (BioRad, Munich, Germany). Equal amounts of protein for each group were separated on a $10 \%$ SDS gel and transfered to an immobilon-PVDF membrane (Millipore Corporation, Bedford, MA). The blots were first probed with antibodies against the phosphorylated forms of the protein and then stripped and probed with antibodies against total proteins of same type. Antibodies were from Cell Signaling (Beverly, MA; pMEK; Ser217/221; 1:1000), pERK1/2 (Thr202/Tyr204; 1:1000), pRSK1 (Thr359/Ser363) (1:1500), pp38 (Thr180/Tyr182) (1:2000), and pJNK1-3 (Thr183/Tyr185) (1:2000), and respective total protein (1:1000)). Immunocomplexes were detected using the ECL method (Amersham Biosciences, Piscataway, NJ). Quantification of the immunoblots was performed by densitometric scanning of the film using NIH ImageJ software. To assess for changes in the phosphorylated kinase levels, they were normalized to respective total kinase levels in hippocampal extracts. Total kinase levels did not differ significantly across genotypes. Normalized phosphorylated kinase levels in $\mathrm{CRF}_{2}-I-$ mice were expressed as a percentage of those in wild-type mice $(+/+)$.

\section{Statistical Analysis}

The data for behavioral and molecular studies are expressed as mean $\pm \mathrm{SEM}$, and were analyzed using a one-way ANOVA with factor genotype and two-way ANOVA with factors treatment and genotype. Bonferroni/Dunn test will be applied, post hoc, for individual between-group comparisons at the $p<0.05$ level of significance.

\section{RESULTS}

In our first experiments, depression-like behavior of male $\mathrm{CRF}_{2}-1-$ mice was measured. Bale and Vale (2003) demonstrated that male and female $\mathrm{CRF}_{2}-/-$ mice show increased immobility, compared to wild-type mice, during a 5 -min test swimming on day 2 in the FST, as an indicator of depression. Similar to results described by Bale and Vale (2003), we observed an elevated depression-like behavior for male $\mathrm{CRF}_{2}-/-$ mice compared to wild-type mice. However, in our experiments, the $\mathrm{CRF}_{2}-/-$ mice showed increased floating $\left(\mathrm{F}_{(1,14)}=14.45 ; p<0.05\right)$ and decreased latency to assume floating posture $\left(\mathrm{F}_{(1,14)}=3.12 ; p<0.05\right)$ only in the $12-\mathrm{min}$ preswim on day 1 (Figure $1 \mathrm{a}$ and $\mathrm{b}$ ), but not in the 5-min test swim session after $24 \mathrm{~h}(p>0.05$ for both behavioral measures; day 2; Figure $1 c$ and $d$ ). In addition, $\mathrm{CRF}_{2}-\mathrm{I}-$ and wild-type mice were examined in the TST. $\mathrm{CRF}_{2}-/-$ mice exhibited an increase in immobility compared to wild-type mice $\left(\mathrm{F}_{(1,14)}=5.15 ; p<0.05\right.$; Figure 1e). Overall, our data confirmed and extended

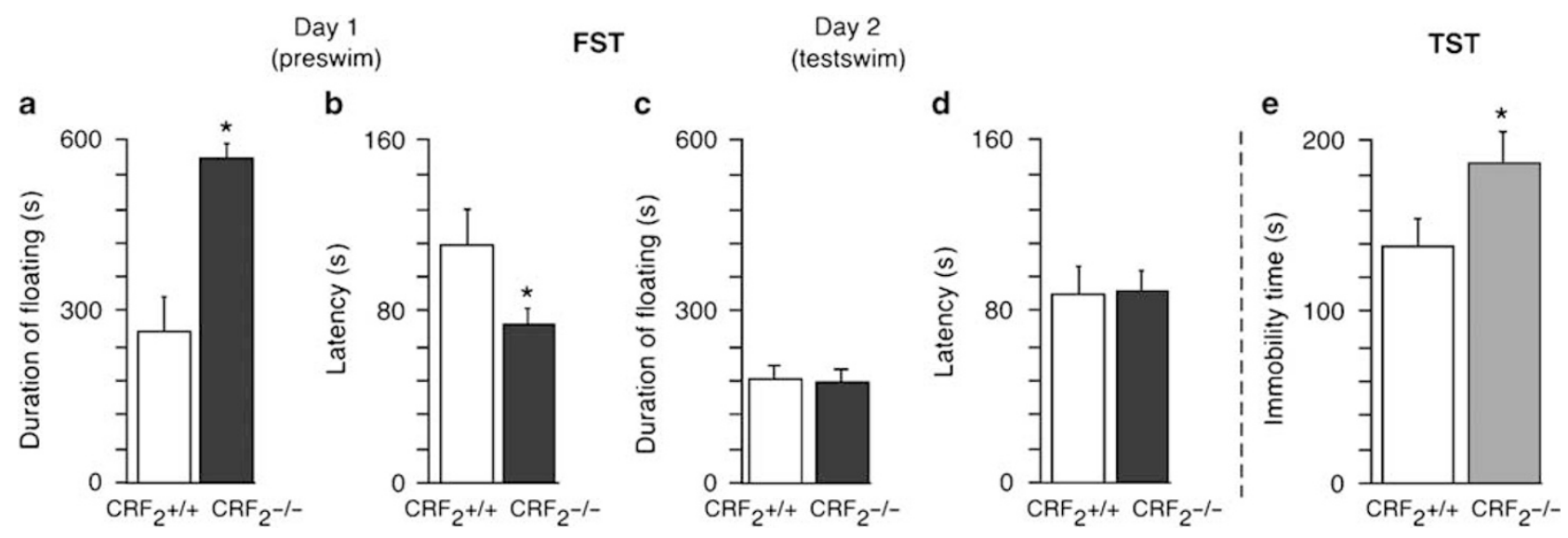

Figure I Increased depression-like behaviors of $\mathrm{CRF}_{2}$-deficient mice in the forced swim test and tail suspension test. Behavior of wild-type and $\mathrm{CRF}_{2}-/-$ mice in the FST. The number of animals per group in the FST test was eight wild-type and eight $\mathrm{CRF}_{2}-1-$ mice. $\mathrm{CRF}_{2}-/-$ male mice showed an increase in time spent passively floating on the preswim on day I (I 2 min) of the FST (a), and decreased latency to attain immobile posture (b). Statistically significant differences: ${ }^{*} P<0.05$, vs wild-type mice. $\mathrm{CRF}_{2}-1-$ mice did not display any significant changes in depression-like behaviors during the test swim (5 min) on day 2 (c and d). Behavior of wild-type, and $\mathrm{CRF}_{2}-1-$ mice in the TST. $\mathrm{CRF}_{2}-1-$ mice demonstrated significantly increased immobility as compared to wildtype mice (eight wild-type and eight $\mathrm{CRF}_{2}-/-$ mice) (e). Bar graphs are mean \pm SEM. Statistically significant differences: $* p<0.05$, vs wild-type littermates. 
previous results that male $\mathrm{CRF}_{2}-/-$ mice display elevated depression-like behaviors.

We next investigated whether the increased depressionlike behavior of male $\mathrm{CRF}_{2}-1-$ mice is caused by differences in activation (phosphorylation) of hippocampal ERK1/2, its upstream activator MEK, and substrate RSK1 implicated in mood regulation (Duman et al, 2007). Therefore, we determined the levels of phosphorylated MEK, ERK1/2, and RSK1 under baseline conditions and $30 \mathrm{~min}$ after exposure to the FST on day 1. In the hippocampal formation, a significant increase in pMEK $\left(\mathrm{F}_{(1,6)}=14.15 ; p<0.05\right) \quad$ pERK1, $\quad\left(\mathrm{F}_{(1,6)}=6.82 ; p<0.05\right)$, pERK2 $\left(\mathrm{F}_{(1,6)}=4.44 ; p<0.05\right)$, and pRSK1 $\left(\mathrm{F}_{(1,6)}=9.56\right.$; $p<0.05)$ was detected in $\mathrm{CRF}_{2}-1-$ mice as compared to the wild-type mice under baseline conditions (Figure $2 \mathrm{a}$ and $\mathrm{b}$ ). Two other subfamilies of MAPKs, c-Jun amino-terminal kinases1-3 and p38 MAPKs, did not differ between genotypes $(p>0.05)$. In the control study, Western blot analysis did not reveal significant changes in MEK, ERK1/2, and RSK1 protein levels in the somatosensory cortex and striatum, indicating relative region-specific alteration of the MEK/ERK pathway in the mutant mice (data not shown). Exposure to the FST for $12 \mathrm{~min}$ on day 1 did not change hippocampal pERK1 and pERK2 activation of $\mathrm{CRF}_{2}-\mathrm{I}-$ mice and their wild-type littermates $(p>0.05$; Figure $2 c)$. Immunohistochemical analysis revealed subfield-specific phosphorylation of ERK1/2 within the hippocampus (Figure 3a), as in the CA3 $\left(\mathrm{F}_{(1,8)}=12.98 ; p<0.05\right.$; Figure $3 \mathrm{~b}$ and e left panel), and $\mathrm{CA} 1\left(\mathrm{~F}_{(1,8)}=8.22 ; p<0.05\right.$; Figure $3 c$ and e right panel), hippocampal subfields, but not the dentate gyrus $(p>0.05)$, pERK1/2 was significantly elevated (Figure 3a-e).

To determine whether MEK/ERK pathway hyperphosphorylation is functionally related to the elevated depression-like behavior observed in $\mathrm{CRF}_{2}-1-$ mice, we tested the effects of U0126, a specific MEK inhibitor (Roberson et al, 1999), on depression-like behaviors in the FST and TST. The U0126 injections were applied i.h. $30 \mathrm{~min}$ before the preswim on day 1 for the FST, and $30 \mathrm{~min}$ before the TST. As no differences between genotypes were observed during the test swim on day 2 of the FST, injections of U0126 were not employed for day 2. Two-way ANOVA (treatment $\times$ genotype) revealed that an i.h. injection of U0126 $(250 \mu \mathrm{g} 0.25 \mu \mathrm{l}$ per side) significantly decreased floating time (treatment, $\mathrm{F}_{(1,26)}=7.46 ; p<0.05$; genotype, $\mathrm{F}_{(1,26)}=2.35$; $p>0.05$; treatment $\times$ genotype, $\left.\mathrm{F}_{(1,26)}=0.67 ; p>0.05\right)$, increased latency time (treatment, $\mathrm{F}_{(1,26)}=11.2 ; p<0.05$; genotype, $\mathrm{F}_{(1,26)}=3.12 ; \quad p>0.05 ; \quad$ treatment $\times$ genotype, $\left.\mathrm{F}_{(1,26)}=1.67 ; p>0.05\right)$ in the FST (Figure $4 \mathrm{a}$ and $\mathrm{b}$ ), and reduced immobility time (treatment, $\mathrm{F}_{(1,26)}=5.2 ; p<0.05$; genotype, $\quad F_{(1,26)}=1.89 ; \quad p>0.05 ;$ treatment $\times$ genotype, $\left.\mathrm{F}_{(1,26)}=0.77 ; p>0.05\right)$ in the TST (Figure $4 \mathrm{~d}$ ), irrespective

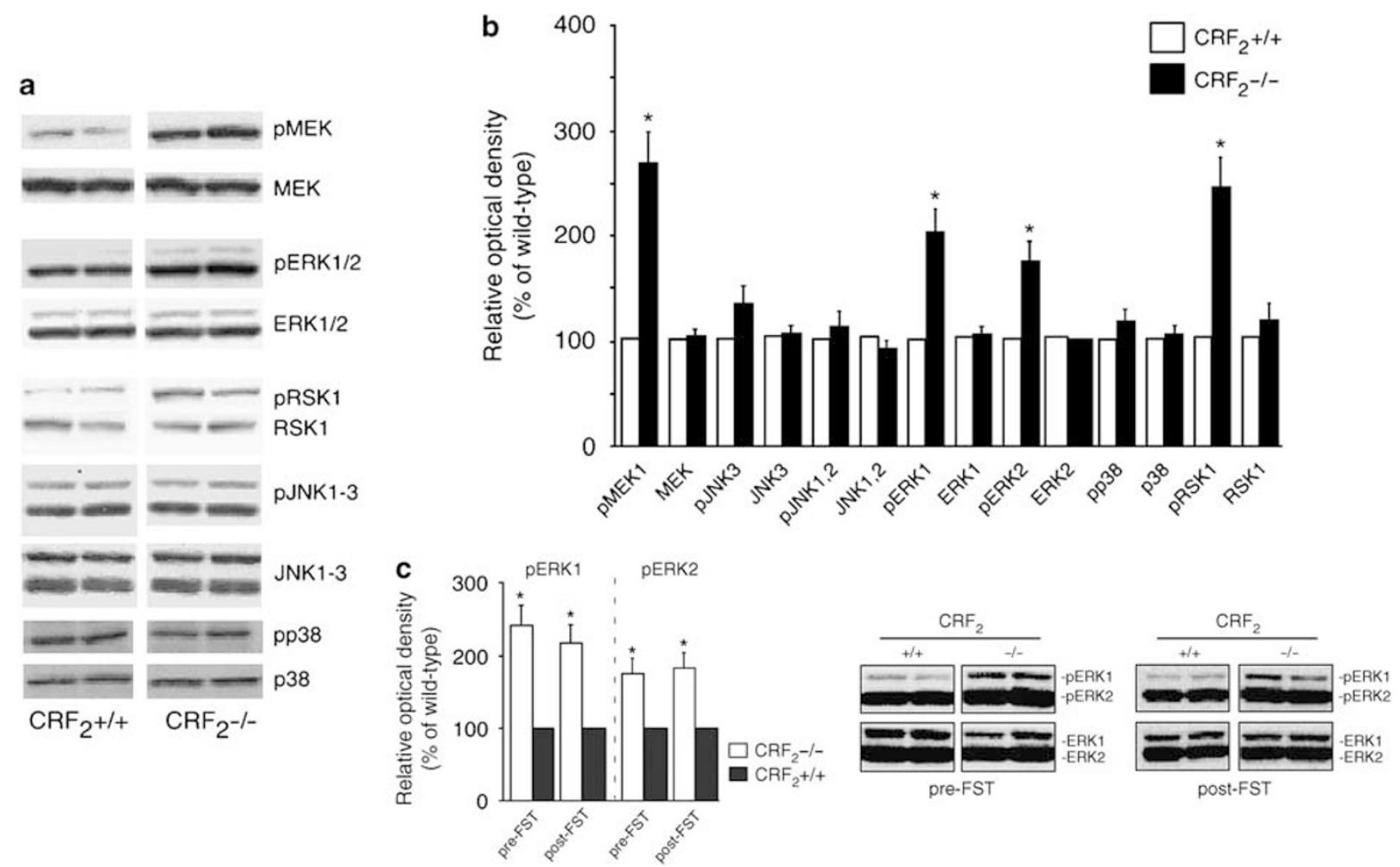

Figure 2 Increased expression of activated proteins in the MEK/ERK pathway in $\mathrm{CRF}_{2}-/$ - mice under basal conditions. Western blot analyses of hippocampal extracts for phosphorylated MEK, ERKI/2, RSKI, JNKI-3, p38, and their respective nonphosphorylated protein forms were carried out using specific antibodies. Hippocampal lysates from $\mathrm{CRF}_{2}-/$ - mice and wild-type littermates were obtained from untreated, nayve mice (a). Quantification by densitometry of the corresponding $X$-ray films. Activated kinase levels in $\mathrm{CRF}_{2}-/-$ mice $(-/-)$ were expressed as a percentage of those in wild-type mice $(+/+)$. Before that calculation, activated kinase levels were normalized to total kinase levels. Differences between wild-type littermates $(+/+)(n=4)$ and $\mathrm{CRF}_{2}-/-(n=4)$ mice were all statistically significant (ANOVA) in the MEK/ERK pathway; $* 0<0.05$ relative to the wild-type $(+/+)$ littermates. Other members of MAPK subfamilies, p38 MAPK, and c-Jun NH2-terminal protein kinasel-3 (JNKI-3) did not differ between genotypes (b). The 12-min (day I) exposure to the FST did not induce elevation of pERKI/2 in hippocampal lysates (wild type, $n=4 ; C_{2} F_{2}-/-, n=4$ ) (c). No changes in total protein amounts were observed. Statistically significant differences: ${ }^{*} p<0.05$, vs wild-type littermates. 
a

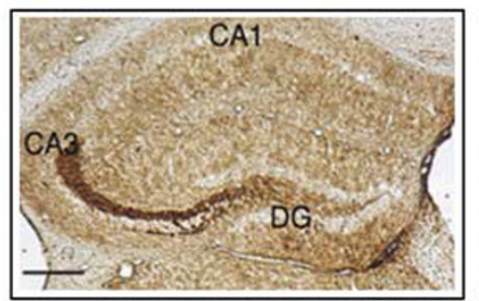

$\mathrm{CRF}_{2++}$

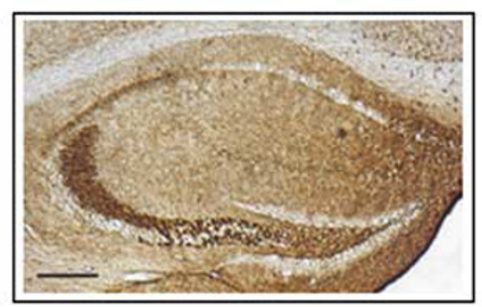

$\mathrm{CRF}_{2}{ }^{-1-}$
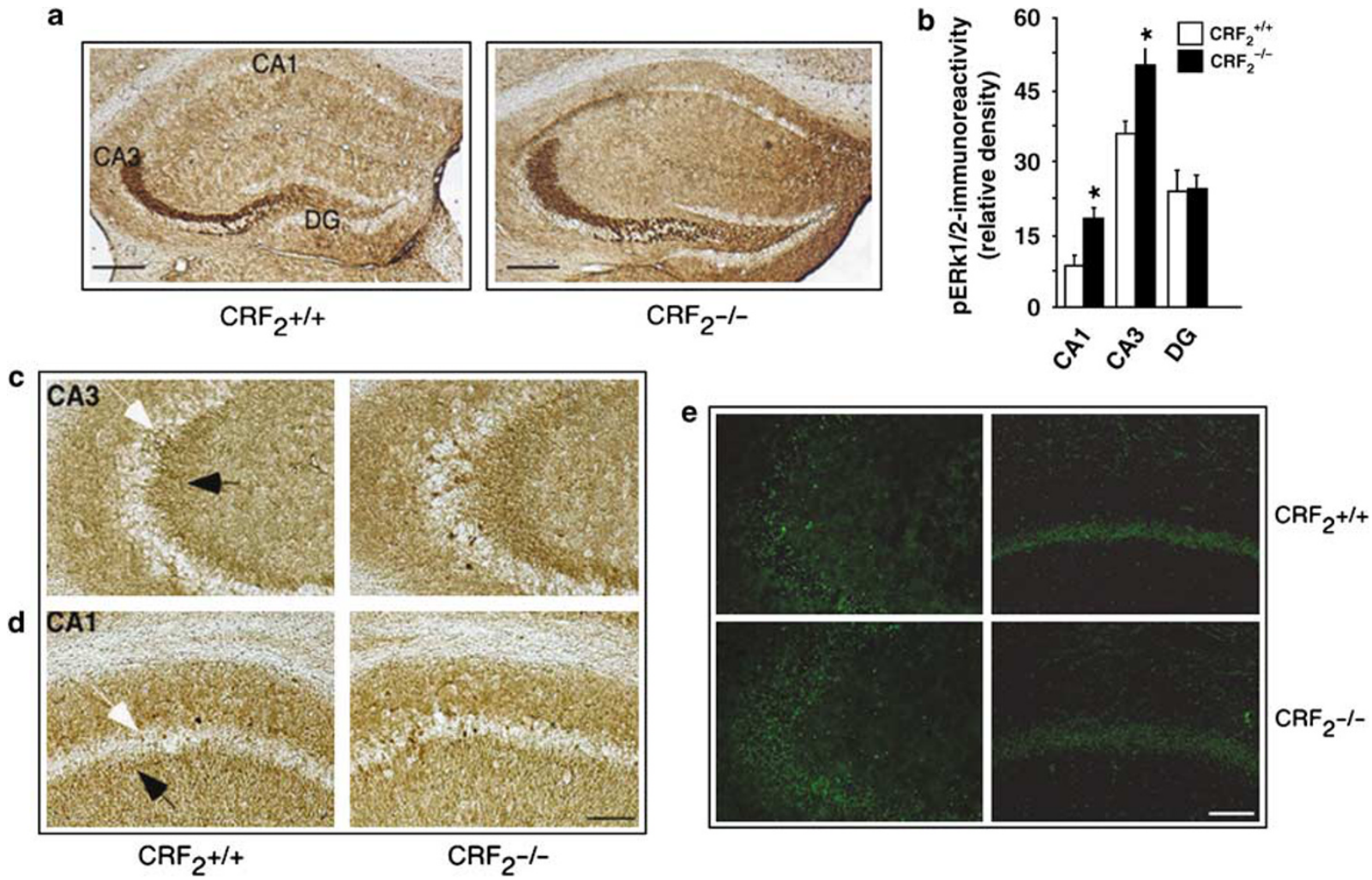

Figure 3 Increased phosphorylation of ERKI/2 in $\mathrm{CRF}_{2}-/$ - mice in the CAI and CA3 hippocampal subfields under baseline conditions. Representative photomicrographs of baseline pERKI/2 labeling in the hippocampus of wild-type $(+/+)$ and $\mathrm{CRF}_{2}-/-$ mice (a). Summarized diagram showing pERKI/2labeled cells in $\mathrm{CRF}_{2}-/-$ mice and their wild-type $(+/+)$ controls. The data are expressed as the relative optical density of pERKI/2-immunoreactivity (mean \pm SEM) in the DG, CAI, and CA3 of the hippocampus ( $n=5$ mice per genotype) Bar graphs are mean \pm SEM. Statistically significant differences: $* 0.05$, vs wild-type littermates (b). High magnification showing pERKI/2 immunostaining of mossy fibers and CA3 pyramidal cells of wild-type $(+/+)$ (left) and $\mathrm{CRF}_{2}-\mathrm{I}-$ mice (right). Black arrows indicate immunostained fibers, and white arrows, nuclear staining (diaminobenzidine was used as a chromogen) (c). High magnification of pERKI/2 immunostaining of CAI pyramidal cells of wild-type $\left(+/+\right.$ ) (left) and $\mathrm{CRF}_{2}-1-$ mice (right). Black arrows indicate immunostained fibers of stratum radiatum, and white arrows indicate nuclear staining (diaminobenzidine was used as a chromogen) (d). Representative images of pERKI/2 fluorescence immunohistochemistry of CA3 (left panel) and CAI (right panel) subregions of the hippocampus in $\mathrm{CRF}_{2}-$ I - mice (lower panel), and wild-type $(+/+$ ) littermates (upper panel) (magnification $\times 20)($ e). CAI, subregion of hippocampus; CA3, subregion of hippocampus; DG, dentate gyrus (scale bar, $110 \mu \mathrm{m}$ (a); $400 \mu \mathrm{m}(\mathrm{c}-\mathrm{e})$ ).

of genotype (Bonferroni/Dunn test; ${ }^{\#} p>0.05$ compared to vehicle-treated mice; ${ }^{*} p>0.05$ compared to vehicle-treated wild-type littermates). To confirm that i.h. administration of the MEK inhibitor U0126 results in inhibition of ERK phosphorylation, we injected mice with U0126 ( $250 \mu \mathrm{g} 0.25 \mu \mathrm{l}$ per side), and $30 \mathrm{~min}$ later, hippocampal tissue was collected for determination of pERK levels. As seen in Figure 4c, $250 \mu \mathrm{g}$ of U0126 significantly decreased basal levels of $\mathrm{pERK} 1 / 2$ in the hippocampus without altering the amount of total ERK (Bonferroni/Dunn test; ${ }^{\star} p<0.05$ compared to vehicle-treated groups). We next examined the locomotor responses to pharmacological inhibition of the hippocampal MEK/ERK pathway. $\mathrm{CRF}_{2}-\mathrm{I}-$ mice and their wild-type littermates received i.h. injection of vehicle or U0126 (250 $\mu \mathrm{g} 0.25 \mu \mathrm{l}$ per side), and were exposed to the locomotor activity test $30 \mathrm{~min}$ later. As revealed by two-way ANOVA (treatment $\times$ genotype) (treatment, $\mathrm{F}_{(1,12)}=0.46 ; p>0.05 ;$ genotype, $\mathrm{F}_{(1,12)}=1.1$; $p>0.05 ; \quad$ treatment $\times$ genotype, $\left.\mathrm{F}_{(1,12)}=0.62 ; p>0.05\right)$, U0126 did not affect locomotor activity in the $\mathrm{CRF}_{2}-\mathrm{I}-$ and control mice (Figure 4e). Overall, these data suggest that the blockade of the MEK/ERK pathway in the hippocampus induces selective antidepressant-like behavioral effects.
We were also interested to examine whether increased hippocampal $\mathrm{CRF}_{1}$ activity in the absence of $\mathrm{CRF}_{2}$ was the possible cause of MEK/ERK pathway hyperphosphorylation, and the increased depression-like behaviors in $\mathrm{CRF}_{2}-\mathrm{I}-$ mice. Figure $5 \mathrm{a}$ shows that i.h. administration of $120 \mathrm{pmol}$ ([Glu $\left.{ }^{11,16}\right]$ Ast $(215 \mathrm{ng} 0.25 \mu$ l per side), resulted in normalization of hippocampal pMEK and pERK1/2 levels in $\mathrm{CRF}_{2}-/-$ mice after $30 \mathrm{~min}$ without changing the amount of total proteins. Moreover, the same treatment did not change pMEK and pERK1/2 levels in the wild-type littermates (Bonferroni/Dunn test; $p>0.05$ compared to vehicle-treated groups; Figure 5a). On the basis of that finding, in the next experiment, $120 \mathrm{pmol}\left[\mathrm{Glu}^{11,16}\right]$ Ast (215 ng $0.25 \mu$ l per side) was applied i.h. to $\mathrm{CRF}_{2}-/-$ mice and wild-type littermates $30 \mathrm{~min}$ before day 1 test of the FST (12 min) and the TST (6 min). Two-way ANOVA did not reveal a significant difference in floating (treatment, $\mathrm{F}_{(1,20)}=1.82 ; p>0.05 ;$ genotype, $\mathrm{F}_{(1,20)}=2.43 ; p>0.05 ;$ treatment $\times$ genotype, $\left.\mathrm{F}_{(1,20)}=1.67 ; p>0.05\right)$, and latency time (treatment, $\mathrm{F}_{(1,20)}=1.22 ; \quad p>0.05$; genotype, $\mathrm{F}_{(1,20)}=2.17 ; p>0.05$; treatment $\times$ genotype, $\mathrm{F}_{(1,20)}=1.33$; $p>0.05)$ in the FST of male $\left[\mathrm{Glu}^{11,16}\right]$ Ast-treated $\mathrm{CRF}_{2^{-}}$ mutant mice compared to vehicle-treated mutant mice (Bonferroni/Dunn test; $p>0.05$; Figure $5 b$ and c). Similarly, 

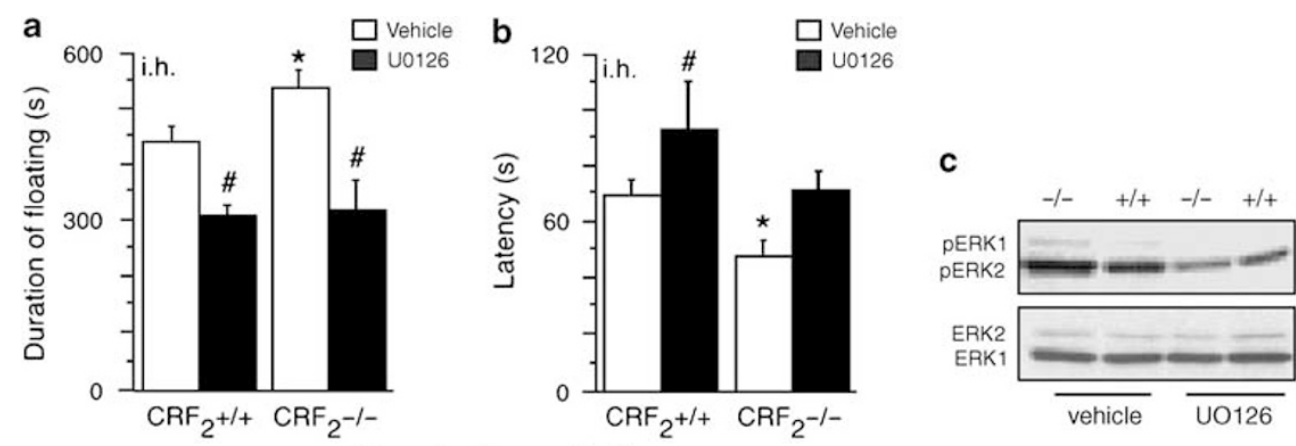

Forced swim test $(a, b)$

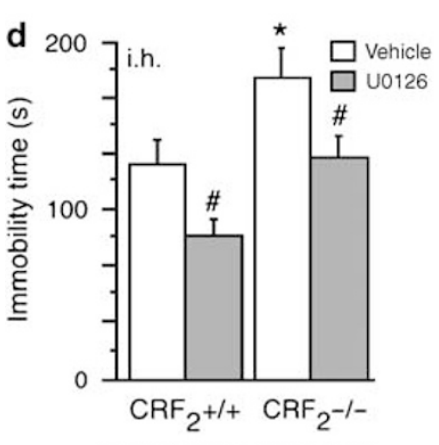

Tail Suspension test

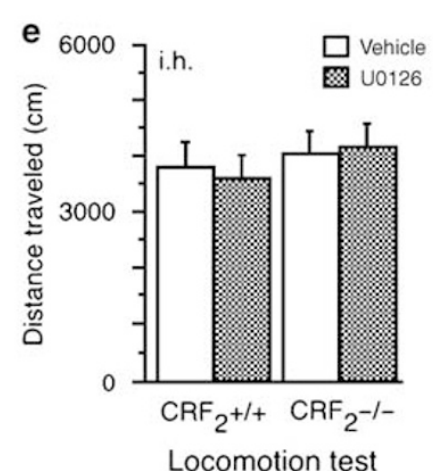

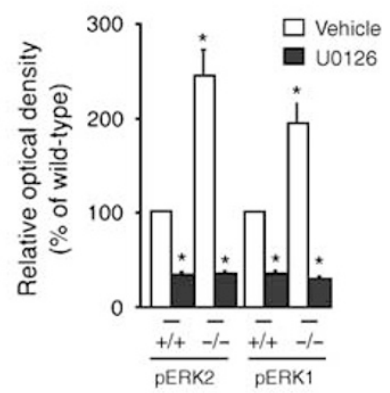

Figure 4 Inhibition of the MEK/ERK pathway in the hippocampus has antidepressant properties in both wild-type and $\mathrm{CRF}_{2}-/-$ mice in the forced swim test and tail suspension test. Intrahippocampal (i.h.) administration of MEK inhibitor U0I26 (250 $\mu$ g $0.25 \mu$ l per side) 30 min before I2-min FST (day I) ( $\mathrm{a}$ and b), or 6-min TST (d), reversed elevated depression-like behaviors of $\mathrm{CRF}_{2}-1-$ mice and showed antidepressant-like properties in the wild-type mice. Locomotor activity as indicated by total distance traveled $(\mathrm{cm})$ was not affected by i.h. U0 I $26(250 \mu \mathrm{g} 0.25 \mu \mathrm{l}$ per side) treatment (e). The number of animals per group in the FST and TST tests was seven for $\mathrm{CRF}_{2}-1-$, and eight for $\mathrm{CRF}_{2}+1+$. For locomotor activity test, number of mice per group was four. Different mice were used for separate tests. Representative blots (left), and mean \pm SEM percent of pERKI and pERK2 immunoreactivity (right) from hippocampal extracts taken from wild-type mice given i.h. infusions of 50\% DMSO (vehicle; $n=4$ mice), or I $\mu$ g $\mu$ l of $\cup 0 \mid 26$ ( $n=4$ mice) (a, b, and d). The immunoblots were obtained from individual hippocampal lysates isolated $30 \mathrm{~min}$ after injection of inhibitor or vehicle. Normalized activated kinase levels in $\mathrm{CRF}_{2}-/-$ mice were expressed as a percentage of those in wild-type mice $(+/+)(\mathrm{c})$. Statistically significant differences: ${ }^{\#} p>0.05$ compared to vehicletreated mice of the same genotype; * $p>0.05$ compared to vehicle-treated wild-type littermates.

the level of immobility detected in the $\left[\mathrm{Glu}^{11,16}\right]$ Ast-treated mutant male mice was similar to that found in vehicletreated wild-type littermates in the TST (Bonferroni/Dunn test; $p>0.05$; Figure $5 \mathrm{~d}$ ). These results demonstrated that administration of $\mathrm{CRF}_{1} / \mathrm{CRF}_{2}$ nonspecific antagonist, $\left[\mathrm{Glu}^{11,16}\right]$ Ast, in $\mathrm{CRF}_{2}-/-$ mice resulted in a balanced activation of the MEK/ERK pathway and attenuated ERKmediated depression-like phenotype, suggesting a role for $\mathrm{CRF}_{1}$ in these processes. Nonspecific blockade of CRF receptors in the hippocampus did not result in altered depression-like behavior, unrelated to mouse genotype.

\section{DISCUSSION}

In these studies, male $\mathrm{CRF}_{2}-/-$ mice showed increased depression-like behaviors in both FST and TST, the most commonly used animal models of depression (Cryan et al, 2002). Male $\mathrm{CRF}_{2}-I-$ mice demonstrated both increased floating time, as well as decreased latency to attain floating posture, compared to their wild-type male littermates in the FST. In addition, $\mathrm{CRF}_{2}-/-$ mice showed a significant increase in immobility time during TST. These behavioral differences between genotypes were functionally coupled with the hyperphosphorylation of the hippocampal MEK/ ERK pathway found in the $\mathrm{CRF}_{2}-1-$ mice. This over- activation of the MEK/ERK pathway is hypothesized to result from the unimpeded activation of hippocampal CRF . $_{1}$ In support of this interpretation, i.h. application of the CRF receptor subtype nonselective antagonist, [Glu $\left.{ }^{11,16}\right]$ Ast, reversed the observed molecular and behavioral differences between genotypes. In addition, i.h. blockade of the MEK/ ERK pathway had antidepressant effects independent of the genotype.

Overall, these results support the prevailing hypothesis that increased $\mathrm{CRF}_{1}$ activity results in increased susceptibility for the development of depression, as earlier studies have demonstrated an involvement of enhanced $\mathrm{CRF}_{1}$ activity or increased production of CRF with the development of depression-like behaviors in rodents and humans (Arborelius et al, 1999; Reul and Holsboer, 2002). Similar to our results, it has been previously reported that male and female $\mathrm{CRF}_{2}-1-$ mice show increased immobility in the FST, and that i.c.v. treatment of $\mathrm{CRF}_{2}-/-$ mice with the $\mathrm{CRF}_{1}$ antagonist, antalarmin, decreases immobility time and increases swim time in both sexes (Bale and Vale, 2003). The same mutants display increased CRF mRNA in the central nucleus of the amygdala, Ucn1 mRNA in the Edinger-Westphal nucleus, and Urocortin3 mRNA levels in the lateral perifornical area (Bale et al, 2000; Bale and Vale, 2003). Taking into account our present finding that i.h. application of CRF receptor subtype nonselective 

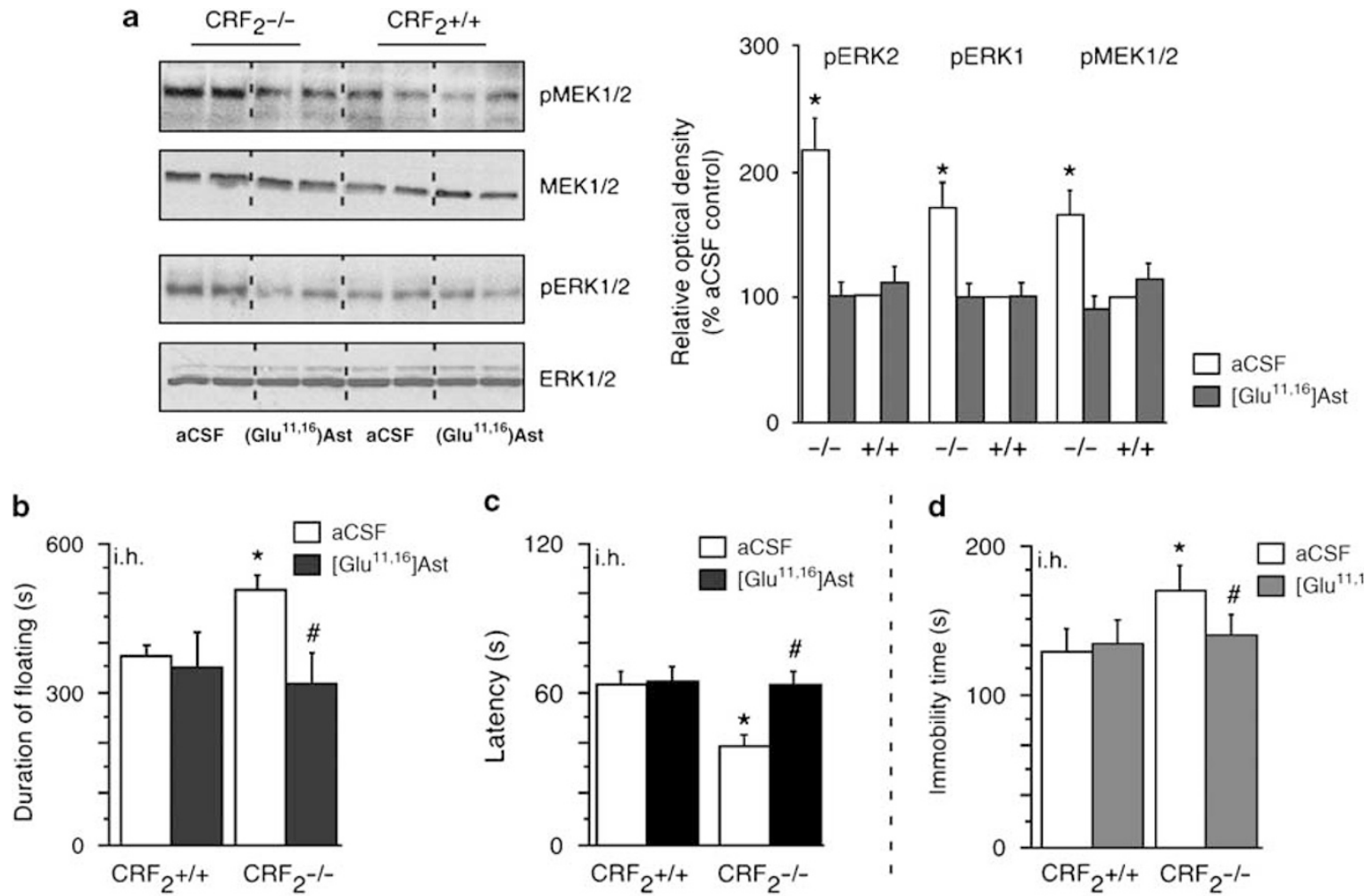

Forced swim test $(b, c)$

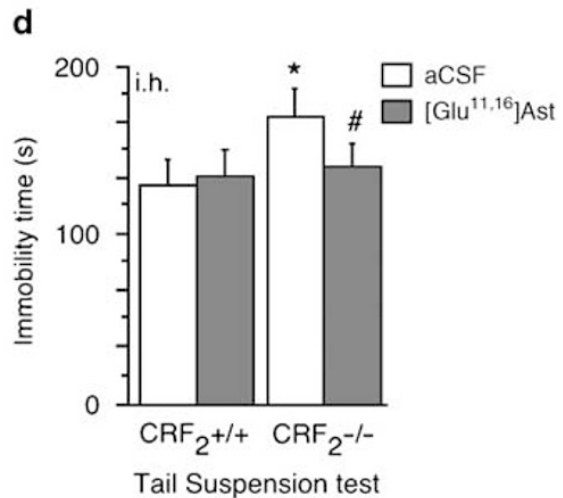

Figure 5 Blockade of $\mathrm{CRF}_{1}$ in the hippocampus normalizes MEK/ERK pathway and reverses depression-like behaviors of $\mathrm{CRF}_{2}-/-$ mice.

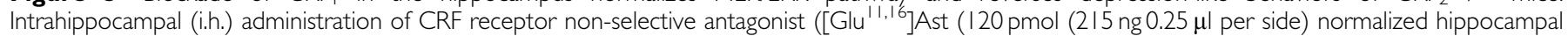
levels of pMEK and pERKI/2 in $\mathrm{CRF}_{2}-/$ - mice. Differences between wild-type $(+/+)(n=3)$ and $\mathrm{CRF}_{2}-/-$ mice $(n=3)$ were not statistically significant: $p>0.05$. The immunoblots were obtained from individual hippocampal lysates obtained 30 min after injection of antagonist or vehicle (a). The same treatment with 120 pmol [Glu ${ }^{11,16}$ ]Ast ( $215 \mathrm{ng} 0.25 \mu \mathrm{l}$ per side, injected i.h.) 30 min before $12 \mathrm{~min}$ FST on day I (b and c), or 6 min TST (d), returned depression-like behaviors of $\mathrm{CRF}_{2}-1$ - mice to baseline levels, without affecting behavior of wild-type mice. The number of animals per group in the FST and TST tests was six for $\mathrm{CRF}_{2}-/-$, and six for wild-type mice $(+/+)$. Different mice were used for separate tests. Statistically significant differences: ${ }^{*} p>0.05$ compared to vehicle-treated mice of the same genotype; $* 0.05$ compared to vehicle-treated wild-type littermates.

antagonist, $\left[\mathrm{Glu}^{11,16}\right]$ Ast, reduced depression-like behaviors of the $\mathrm{CRF}_{2}-/-$ mice, it is conceivable that the deregulation of a circuitry involving the central nuclei of the amygdala and the hippocampal CRF receptors may result in a predisposition for developing the depression-dominated phenotype (Swanson and Cowan, 1977). It is worth noting, that i.h. application of $\left[\mathrm{Glu}^{11,16}\right]$ Ast did not affect depression-like behaviors of wild-type mice. As $\mathrm{CRF}_{1}$ antagonists are most effective in producing an antidepressant effect when applied to animals bred for high innate anxiety or previously exposed to stress, more often than not, $\mathrm{CRF}_{1}$ antagonists do not affect baseline depression-related behaviors when rodents are tested in the standard or modified FST or TST. (Keck et al, 2001; Hauger et al, 2006). As we recently suggested, antagonism of $\mathrm{CRF}_{1}$ may be especially effective in treating individuals who are genetically predisposed to develop anxiety and affective disorders, or who have been exposed to stress by means of 'priming' sensitizing them to subsequent stress challenges (Sherrin et al, 2008).

Our data indicating that $\mathrm{CRF}_{2}-/-$ mice showed increased immobility only during the preswim, but not in the test swim session $24 \mathrm{~h}$ later (days 1 and 2, respectively) are seemingly at odds with the previous study in which the $\mathrm{CRF}_{2}-/-$ mice display increased immobility during test swim session (day 2) (Bale and Vale, 2003). Certain procedural differences between the studies merit mentioning. Firstly, the latter study did not measure depression-like behaviors on day 1 . Secondly, mice were placed in the water for a preswim for $5 \mathrm{~min}$ on day 1 and then monitored during a 5 -min test $24 \mathrm{~h}$ after the preswim, totaling $10 \mathrm{~min}$ of forced swimming (Bale and Vale, 2003), whereas duration of the forced swimming in our study totaled 12 min already on day 1 (preswim), the time frame in which Bale and Vale (2003) observed the differences between the genotypes. The absence of the differences between genotypes on day 2, observed in our study, might be put in the framework of a series of findings showing that $\mathrm{CRF}_{1}$ and $\mathrm{CRF}_{2}$ regulate the DRN serotonergic system in an opposite manner (Price et al, 2002; Hammack et al, 2003). In short, studies utilizing FST, demonstrate that $\mathrm{CRF}_{1}$ mediates inhibition of the DRN serotonergic system, which facilitates short-term, active defensive responses that can be quickly terminated, whereas $\mathrm{CRF}_{2}$ mediates excitation of this system, which promotes long-term, passive defensive responses (Valentino and Commons, 2005). It is possible, therefore, that in the absence of $\mathrm{CRF}_{2}, \mathrm{CRF}_{1}$-facilitated short-term defensive responses dominated, whereas $\mathrm{CRF}_{2}$-mediated passive long-term, defensive responses, characteristic of learned helplessness, were absent on day 2 of the FST in $\mathrm{CRF}_{2}-\mathrm{I}-$ 
mice. In such case, the balance between innate and learned depression-related behavioral tendencies would favor the loss of hippocampally driven depressant phenotype observed on day 1 .

As noted, i.c.v. injection of $\mathrm{h} / \mathrm{rCRF}$ induces strong ERK1/2 activation in the CA3 and CA1 hippocampal subfields and basolateral complex of the amygdala. However, CRFinduced phosphorylation of ERK1/2 is absent in low-anxiety mice with a conditional knockout of forebrain and limbic $\mathrm{CRF}_{1}$ (Refojo et al, 2005). Hence, $\mathrm{CRF}_{1}$ signaling through the MEK/ERK pathway may play a role in anxiogenesis and depression. In accordance, we found that $\mathrm{CRF}_{2}-1-$ mice exhibit increased levels of pERK1/2 activator pMEK, pERK1/2, and pERK1/2 substrate, pRSK1, in the CA1 and CA3 subfields of the hippocampus. These results suggest that overactivation of $\mathrm{CRF}_{1}$ in these areas might stimulate activity of the MEK/ERK pathway. This suggestion was supported by the finding that local injection of $\left[\mathrm{Glu}^{11,16}\right]$ Ast returned the MEK/ERK pathway activity to the level observed in wild-type mice. In short, these data point to the possibility that hippocampal $\mathrm{CRF}_{1}$ overdrive stimulates the MEK/ERK pathway, which causes depression-like behaviors in $\mathrm{CRF}_{2}-I-$ mice. In line with this, i.h. injection of the selective MEK inhibitor, U0126, dramatically decreased the floating and immobility time in the FST and TST, respectively, both in wild-type and mutant mice. Broadly, enhanced $\mathrm{CRF}_{1}$ activity might be attributable to a deficiency in desensitization of receptor, either to mechanisms that switch $\mathrm{CRF}_{1}$ signaling from one mode of Gprotein signaling to another, or to intracellular mechanisms regulating the magnitude and duration of $\mathrm{CRF}_{1}$ signal in $\mathrm{CRF}_{2}-1-$ mice (Steckler and Dautzenberg, 2006). The exact mechanism of the observed molecular changes induced by $\mathrm{CRF}_{2}$-deficiency/CRF $\mathrm{C}_{1}$ overdrive is the subject of present studies in our laboratory.

Our results need to be discussed in the context of data demonstrating that chronic administration of antidepressants, which increase the synaptic concentration of serotonin and/or norepinephrine, appear to activate the MEK/ERK signaling pathway in certain brain structures (Nestler et al, 2002; Coyle and Duman, 2003; Huang and Lin, 2006; Gourley et al, 2008). In line with these findings, systemic acute blockade of MEK/ERK signaling produces a depressive-like phenotype and blocks behavioral actions of antidepressants in the mouse models of depression (Duman et al, 2007). Using acute treatments as employed here, it has recently been reported that activation of ERK1/2 also acts as a depressant within the amygdala and prefrontal cortex (Huang and Lin, 2006; Qi et al, 2006). Those findings may appear inconsistent with our results at first glance. However, taking into consideration that acute and subacute (ie, three doses over a 24-h period) systemic MEK inhibition produce opposite effects on FST behavior (Duman et al, 2007), it remains to be elucidated whether multiple treatments or the use of different doses would consistently show depressant effects in the hippocampus, amygdala, and prefrontal cortex. Also, a growing body of data suggests that region-specific manipulation of the MEK/ERK pathway may bring about quite distinct affective behavioral phenotypes (Newton et al, 2002; Einat et al, 2003). In particular, a recent finding that i.h. blockade of the MEK/ERK pathway in mice lacking ERK1 reduces the depressive-like phenotype caused by overactivation of ERK2 (Tronson et al, 2008), suggests that ERK mediates depressant actions through the hippocampus (Fumagalli et al, 2005: Tronson et al, 2008), and antidepressant actions through other brain sites like the prefrontal cortex (Qi et al, 2006).

We have previously demonstrated that $\mathrm{CRF}_{2}-1-$ mice do not show alterations of locomotor activity, which would be a potential confound variable for the assessment of floating behavior, latency in the FST, and immobility time in the TST (Kishimoto et al, 2000). In addition, locomotor effects of i.h. U0126 were avoided by employing a dose that did not increase locomotion in the locomotor activity test, but instead selectively diminished the depressive-like phenotype of $\mathrm{CRF}_{2}-/-$ mice.

It should also be mentioned, that recently, based on the FST, we described that the potent $\mathrm{CRF}_{1}$-selective agonist cortagine produces antidepressant-like effects similar to the $\mathrm{CRF}_{1}$ antagonists (Tezval et al, 2004). This is in apparent contrast to FST studies that found antidepressant-like effects by central $\mathrm{CRF}_{1}$ antagonism (Overstreet and Griebel, 2004; Hodgson et al, 2007), as well as with results of this study. In addition, cortagine decreases the distance traveled in the elevated plus maze (EPM), and so reduces mobility (Tezval et al, 2004). On the basis of this decrease of mobility in the EPM, it would not be sufficient to suggest that the effects of cortagine in the FST are simply locomotor effects (Swiergiel et al, 2008). Attempting to reconcile these results, Farrokhi et al, (2007) recently noted that interpretation of behaviors might depend on the model employed. They suggest that anxiety-like or defensive responses may be affected by the options available for dealing with a threat source (Blanchard et al, 1997). A more potent stress source with limited options for responding, such as the FST, allows two options: increase the swim rate to attempt escaping, or become immobile. The EPM provides more options, and the alternative of retreat to an area of relative safety rather than struggling to escape. Thus, comparing the measure of mobility in both tests as an index for emotionality may not be appropriate. Although the FST may be a useful screening model for antidepressant effects of drugs (Lucki, 1997), it may be a weak indicator of emotionality with compounds like cortagine that also produce locomotor effects or high levels of anxiety (Farrokhi et al, 2007). Further preclinical research is necessary to determine the exact role of $\mathrm{CRF}_{1}$ in depression-related behaviors.

This is of particular importance, given that the concept that abnormally enhanced central $\mathrm{CRF} / \mathrm{CRF}_{1}$ signaling contributes to the pathophysiology of major depression was recently questioned, after clinical trials employing small molecule $\mathrm{CRF}_{1}$ receptor antagonists in patients with major depression yielded inconsistent results (Zobel et al, 2000; Binneman et al, 2008). Although in a preliminary open-label clinical trial, oral administration of the $\mathrm{CRF}_{1}$ receptor antagonist NBI-30775 decreases depression and anxiety scores in patients with major depression, presumably by blocking the activity of hyperactive $\mathrm{CRF}_{1}$ receptors in brain regions mediating symptoms of depression (Zobel et al, 2000 ), recent randomized, placebo controlled trial finds that another $\mathrm{CRF}_{1}$ antagonist CP-316311 fails to demonstrate efficacy in the treatment of major depression (Binneman et al, 2008). Even though it is difficult to reconcile such apparent inconsistency, it should be kept in mind that 
probably only in a certain subpopulation of patients altered $\mathrm{CRF}_{\mathrm{CRF}}$ signaling might account for the etiology and symptoms of major depression. This renders heterogeneity among trials in clinical setting highly probable.

In summary, our results have confirmed previous results (Bale and Vale, 2003; Todorovic et al, 2005) that show a significant increase in depression-like behaviors in $\mathrm{CRF}_{2}-/-$ mice. Presumably chronically elevated CRF and Ucn1 levels acting on the hippocampal $\mathrm{CRF}_{1}$ led to overactivation of the MEK/ERK pathway that might be contributing to the detected depressive-like phenotype of mutants. Additional studies examining the involvement of CRF family members, as well as other distinct neurotransmitter systems, will provide necessary information concerning the genetic and neurobiological basis for the complex relationship between stress and depression.

\section{ACKNOWLEDGEMENTS}

This study was supported by Max Planck Society, NIH Grant 5U54NS039406-08, and NMRC Grant (NMRC/0754/ 2003).

\section{CONFLICT OF INTEREST}

The authors declare no conflict of interest.

\section{REFERENCES}

Ahi J, Radulovic J, Spiess J (2004). The role of hippocampal signaling cascades in consolidation of fear memory. Behav Brain Res 149: 17-31.

Arborelius L, Owens MJ, Plotsky PM, Nemeroff CB (1999). The role of corticotropin-releasing factor in depression and anxiety disorders. J Endocrinol 160: 1-12.

Bale TL, Contarino A, Smith GW, Chan R, Gold LH, Sawchenko PE et al (2000). Mice deficient for corticotropin-releasing hormone receptor-2 display anxiety-like behaviour and are hypersensitive to stress. Nat Genet 24: 410-414.

Bale TL, Vale WW (2003). Increased depression-like behaviors in corticotropin-releasing factor receptor-2-deficient mice: sexually dichotomous responses. J Neurosci 23: 5295-5301.

Binneman B, Feltner D, Kolluri S, Shi Y, Qiu R, Stiger T (2008). A 6-week randomized, placebo-controlled trial of CP-316311 (a selective CRH1 antagonist) in the treatment of major depression. Am J Psychiatry 165: 617-620.

Blanchard RJ, Griebel G, Henrie JA, Blanchard DC (1997). Differentiation of anxiolytic and panicolytic drugs by effects on rat and mouse defense test batteries. Neurosci Biobehav Rev 21: 783-789.

Chalmers DT, Lovenberg TW, De Souza EB (1995). Localization of novel corticotropin-releasing factor receptor (CRF-2) mRNA expression to specific subcortical nuclei in rat brain: Comparison with CRF-1 receptor mRNA expression. J Neurosci 15: $6340-6350$.

Chen AM, Perrin MH, Digruccio MR, Vaughan JM, Brar BK, Arias $\mathrm{CM}$ et al (2005). A soluble mouse brain splice variant of type 2alpha corticotropin-releasing factor (CRF) receptor binds ligands and modulates their activity. Proc Natl Acad Sci USA 102: $2620-2625$.

Coyle JT, Duman RS (2003). Finding the intracellular signaling pathways affected by mood disorder treatments. Neuron 38: $157-160$
Cryan JF, Markou A, Lucki I (2002). Assessing antidepressant activity in rodents: recent developments and future needs. Trends Pharmacol Sci 23: 238-245.

Cryan JF, Mombereau C, Vassout A (2005). The tail suspension test as a model for assessing antidepressant activity: review of pharmacological and genetic studies in mice. Neurosci Biobehav Rev 29: 571-625.

Duman CH, Schlesinger L, Kodama M, Russell DS, Duman RS (2007). A role for MAP kinase signaling in behavioral models depression and antidepressant treatment. Biol Psychiatry 61: 661-670.

Eckart K, Jahn O, Radulovic J, Tezval H, van Werven L, Spiess J (2001). A single amino acid serves as an affinity switch between the receptor and the binding protein of corticotropin-releasing factor: implications for the design of agonists and antagonists. Proc Natl Acad Sci USA 98: 11142-11147.

Einat H, Yuan P, Gould TD, Li J, Du J, Zhang L et al (2003). The role of the extracellular signal-regulated kinase signaling pathway in mood modulation. J Neurosci 23: 7311-7316.

Farrokhi CB, Tovote P, Blanchard RJ, Blanchard DC, Litvin Y, Spiess J (2007). Cortagine: behavioral and autonomic function of the selective CRF receptor subtype 1 agonist. CNS Drug Rev 13: 423-443.

Franklin K, Paxinos G (1997). The Mouse Brain in Stereotaxic Coordinates. Academic Press: San Diego.

Fumagalli F, Molteni R, Calabrese F, Frasca A, Racagni G, Riva MA (2005). Chronic fluoxetine administration inhibits extracellular signal-regulated kinase $1 / 2$ phosphorylation in rat brain. J Neurochem 93: 1551-1560.

Gourley SL, Wu FJ, Kiraly DD, Ploski JE, Kedves AT, Duman RS et al (2008). Regionally specific regulation of ERK MAP kinase in a model of antidepressant-sensitive chronic depression. Biol Psychiatry 63: 353-359.

Hammack SE, Schmid MJ, LoPresti ML, Der-Avakian A, Pellymounter MA, Foster AC et al (2003). Corticotropin releasing hormone type 2 receptors in the dorsal raphe nucleus mediate the behavioral consequences of uncontrollable stress. J Neurosci 23: $1019-1025$.

Hammen C (2005). Stress and depression. Annu Rev Clin Psychol 1: 293-319.

Hauger RL, Risbrough V, Brauns O, Dautzenberg FM (2006). Corticotropin releasing factor (CRF) receptor signaling in the central nervous system: new molecular targets. CNS Neurol Disord Drug Targets 5: 453-479.

Heinrichs SC, Koob GF (2004). Corticotropin-releasing factor in brain: a role in activation, arousal, and affect regulation. J Pharmacol Exp Ther 311: 427-440.

Hodgson RA, Higgins GA, Guthrie DH, Lu SX, Pond AJ, Mullins DE et al (2007). Comparison of the V1b antagonist, SSR149415, and the CRF1 antagonist, CP-154526, in rodent models of anxiety and depression. Pharmacol Biochem Behav 86: 431-440.

Huang TY, Lin CH (2006). Role of amygdala MAPK activation on immobility behavior of forced swim rats. Behav Brain Res 173: 104-111.

Keck ME, Welt T, Wigger A, Renner U, Engelmann M, Holsboer F et al (2001). The anxiolytic effect of the $\mathrm{CRH}(1)$ receptor antagonist R121919 depends on innate emotionality in rats. Eur J Neurosci 13: 373-380.

Kessler RC (1997). The effects of stressful life events on depression. Annu Rev Psychol 48: 191-214.

Kishimoto T, Radulovic J, Radulovic M, Lin CR, Schrick C, Hooshmand F et al (2000). Deletion of Crhr2 reveals an anxiolytic role for corticotropin-releasing hormone receptor-2. Nat Genet 24: 415-419.

Lucki I (1997). The forced swim test as a model for core and component behavioral effects of antidepressant drugs. Behav Pharmacol 8: 523-532. 
Nestler EJ, Barrot M, DiLeone RJ, Eisch AJ, Gold SJ, Monteggia LM (2002). Neurobiology of depression. Neuron 34: 13-25.

Newton SS, Thome J, Wallace TL, Shirayama Y, Schlesinger L, Sakai N et al (2002). Inhibition of cAMP response elementbinding protein or dynorphin in the nucleus accumbens produces an antidepressant-like effect. J Neurosci 22: 1088310890.

Overstreet DH, Griebel G (2004). Antidepressant-like effects of CRF1 receptor antagonist SSR125543 in an animal model of depression. Eur J Pharmacol 497: 49-53.

Porsolt RD, Bertin A, Jalfre M (1978). 'Behavioural despair'in rats and mice: strain differences and the effects of imipramine. Eur Pharmacol 51: 291-294.

Price ML, Kirby LG, Valentino RJ, Lucki I (2002). Evidence for corticotropin-releasing factor regulation of serotonin in the lateral septum during acute swim stress: adaptation produced by repeated swim. Psychopharmacology 162: 406-414.

Qi X, Lin W, Li J, Pan Y, Wang W (2006). The depressive-like behaviors are correlated with decreased phosphorylation mitogen-activated protein kinases in rat brain following chronic forced swim stress. Behav Brain Res 175: 233-240.

Refojo D, Echenique C, Müller MB, Reul JM, Deussing JM, Wurst W et al (2005). Corticotropin-releasing hormone activates ERK1/ 2 MAPK in specific brain areas. Proc Natl Acad Sci USA 102: 6183-6188.

Reul JM, Holsboer F (2002). Corticotropin-releasing factor receptors 1 and 2 in anxiety and depression. Curr Opin Pharmacol 2: 23-33.

Roberson ED, English JD, Adams JP, Selcher JC, Kondratick C, Sweatt JD (1999). The mitogen-activated protein kinase cascade couples PKA and PKC to cAMP response element binding protein phosphorylation in area CA1 of hippocampus. J Neurosci 19: 4337-4348.

Schüle C (2007). Neuroendocrinological mechanisms of actions of antidepressant drugs. J Neuroendocrinol 19: 213-226.

Sherrin T, Todorovic C, Zeyda T, Tan CH, Hon PW, Zhu YZ et al (2008). Chronic stimulation of corticotropin-releasing factor receptor 1 enhances the anxiogenic response of the cholecystokinin system. Mol Psychiatry Jan 15 (e-pub ahead of print).

Smith GW, Chen R, Marchuk Y, Hauser C, Bentley CA, Sawchenko PE et al (1998). Corticotropin releasing factor receptor 1-deficient mice display decreased anxiety, impaired stress response, and aberrant neuroendocrine development. Neuron 20: 1093-1102.

Steckler T, Dautzenberg FM (2006). Corticotropin-releasing factor receptor antagonists in affective disorders and drug dependence - an update. CNS Neurol Disord Drug Targets 5: 147-165.

Swanson LW, Cowan WM (1977). An autoradiographic study of the organization of the efferent connections of the hippocampal formation in the rat. J Comp Neurol 172: 49-84.

Swiergiel AH, Leskov IL, Dunn AJ (2008). Effects of chronic and acute stressors and CRF on depression-like behavior in mice. Behav Brain Res 186: 32-40.

Tezval H, Jahn, O, Todorovic C, Sasse A, Eckart K et al (2004). Cortagine, a specific agonist of corticotropin-releasing factor receptor subtype 1 , is anxiogenic and antidepressive in the mouse model. Proc Natl Acad Sci USA 101: 9468-9473.

Timpl P, Spanagel R, Sillaber I, Kresse A, Reul JM, Stalla GK et al (1998). Impaired stress response and reduced anxiety in mice lacking a functional corticotropin-releasing hormone receptor 1 . Nat Genet 19: 162-166.

Todorovic C, Jahn O, Tezval H, Hippel C, Spiess J (2005). The role of CRF receptors in anxiety and depression: implications of the novel CRF1 agonist cortagine. Neurosci Biobehav Rev 29: $1323-1333$.

Tronson NC, Schrick C, Fischer A, Sananbenesi F, Pagès G, Pouysségur J et al (2008). Regulatory Mechanisms of Fear Extinction and Depression-Like Behavior. Neuropsychopharmacology 33: 1570-1583.

Vale WW, Spiess J, Rivier C, Rivier J (1981). Characterization of a 41-residue ovine hypothalamic peptide that stimulates secretion of corticotropin and beta-endorphin. Science 213: 1394-1397.

Valentino RJ, Commons KG (2005). Peptides that fine-tune the serotonin system. Neuropeptides 39: 1-8.

Van Pett K, Viau V, Bittencourt JC, Chan RK, Li HY, Arias C et al (2000). Distribution of mRNAs encoding CRF receptors in brain and pituitary of rat and mouse. J Comp Neurol 428: 191-212.

Zobel AW, Nickel T, Kunzel HE, Ackl N, Sonntag A, Ising M et al (2000). Effects of the high-affinity corticotropin-releasing hormone receptor 1 antagonist R121919 in major depression: the first 20 patients treated. J Psychiatr Res 34: 171-181. 